Emad A. Jaffar Al-Mulla ${ }^{1 *}$, Sahar M. Makky²

${ }^{1}$ Al-Furat Al-Awsat Technical University, Faculty of Health and Medical Techniques, An-Najaf, Iraq; ${ }^{2}$ University of Kufa, Department of Chemistry, Faculty of Science, An-Najaf, Iraq
Scientific paper

ISSN 0351-9465, E-ISSN 2466-2585

UDC:665.637.3.001.76

doi: $10.5937 /$ ZasMat1703394A

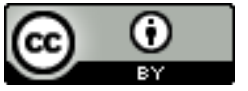

Zastita Materijala 58 (3)

394 - 399 (2017)

\title{
Preparation of sustainable asphalt pavements using polyethylene terephthalate waste as a modifier
}

\begin{abstract}
Industrial development and contemporary life style led to spread a large amounts of nonbiodegradable plastic waste. This paper aims to study the effects of recycling polyethylene terephthalate (PET) plastic waste which is a type of disposable plastic packaging waste as an asphalt modifier, to create a sustainable asphalt pavement and improving the rheological properties and temperature susceptibility. PET waste was blended with asphalt cement in three percentages $(0.5 \%, 0.75 \%$, and $1.0 \%)$ by mass of asphalt cement. The performance of modified asphalt samples have been studied and compared with an unmodified asphalt binder. The penetration, softening point and ductility were carried out to evaluate the influence of adding waste $P E T$ to asphalt on binder characteristics, binder stiffness at different temperatures also studied and all markedly improved. The results show that adding PETW has a significant effect on the rheological behavior and binder stiffness in high temperatures. This study indicate that waste PET has enhance asphalt properties to minimize the paving costs and reduce solid waste environmental problems.
\end{abstract}

Keywords: asphalt; moifier; polyethylene terephthalate waste; physical properties.

\section{INTRODUCTION}

Asphalt concrete mixture has been an important construction materials for highways and airfield pavements [1-3].It consists of mineral aggregate in a combination with bituminous binder (bitumen). Bitumen is an organic mixture forming from various chemical compounds and it is a very resistive material but when it exposed to different weather condition such as heat, oxygen and UV light the chemical structures and physical properties will be change, which is called aging [3]. Also increasing the number and weight of vehicles which passes on roads cause greater damages as a result, the most common distortions are rutting, decreased skid resistance and surface cracks [4]. That led to persistent need to improve the specification of asphalt pavement, using modified asphalt has played an important role to reduce pavement problems by improving thermal and physical properties which affected on the final performance of the mixture [5].

\footnotetext{
${ }^{*}$ Corresponding author: Emad A. Jaffar Al-Mulla E-mail: imad.almulla@uokufa.edu.iq

Paper received: 26. 06. 2017.

Paper accepted: 30. 07. 2017.

Paper is available on the website: www.idk.org.rs/journal
}

The first patent registered of asphalt modification by adding polymers goes back to 1843 , while the first serious utilization of polymers in modification of bituminous mixtures in the 1990s [6].Today there are several types of asphalt mixtures use for different purposes, and prepared by adding different modifications [7]. But utilizing of polymers in asphalt modification are relatively costly for paving roads [8]. So using of waste materials in asphalt improvement (as a polymer additive) would be beneficial to enhance the properties of asphalt pavement, thus will increase of pavement life and decreasing the environmental pollution also [9-10]. The increasing of pavement life not only effect on maintenance intervals and costs but also help to save the energy used for maintenance which mean create sustainable pavements [9]. Environmental and climate protection became the focus of public attention, so the road construction industry must aim to be more sustainable in order to aid in tackling climatic change [11]. From the other side it is important to note that not all of the waste material are suitable to use for asphalt improvement [12].

The majority plastic bottle is made from PET. It becomes waste after a few time from purchase, thus it is considered as a real problem because the 
chemical recycling of PET is Costly [13]. Hence, chemical recycling cannot be the perfect process to predomination on the crisis which arises from huge amount of PET waste[4]. Consequently, use PET as a combined modifier in asphalt mixture considered rational and efficient way to solve this problem. Previous studies have shown that using PET in concrete mixes can improve the rutting resistance[6]. Another studies stated that the development of technology allow using recycle materials to increase stiffness, durability and enhance appearance[14]. On the other hand, utilization of $(1.18 \mathrm{~mm})$ PET size effect on rutting resistance and stiffness of bituminous mixture and produced lower binder drain down[9]. The researchers also reported there is a marked increase in softening point and viscosity in recycled PET modified bitumen [15]. Previous study also demonstrated that higher stability was obtained by adding $0.2-0.8 \%$ of PET [16]. The main objective of this study was to characterized the physical properties of bituminous mixture which prepared by adding different percentage of PET waste. Consequently, determined the optimum amount of the waste which is required to improve the asphalt binder.

\section{MATERIALS AND EXPERIMENTAL METHODS}

\subsection{Bituminous material}

Local asphalt cement produced by AL-Nasiriya Refinery in DHIQAR_IRAQ (350 km South of Baghdad) are used. The binder was 40/50 penetration grade, this grade is the most popular asphalt binder used in highway industry in Iraq. Its physical properties are presented in Table 1.

Tabela 1. Fizičke osobine asfaltnog veziva

Table 1. Physical properties of asphalt binder

\begin{tabular}{|c|c|c|}
\hline Values & Methods & Properties \\
\hline $\begin{array}{c}48 \\
(0.1 \mathrm{~mm})\end{array}$ & ASTM: D-5 & $\begin{array}{c}\text { Penetration } \\
\left(25^{\circ} \mathrm{C}, 100 \mathrm{~g}\right)\end{array}$ \\
\hline 56 & ASTM: D-36 & $\begin{array}{c}\text { Softening point } \\
\text { (ring \& ball) }\end{array}$ \\
\hline$>100 \mathrm{~cm}$ & ASTM: D-113 & $\begin{array}{c}\text { Ductility } \\
\text { at } 25^{\circ} \mathrm{C}\end{array}$ \\
\hline & ASTM: D-4402 & $\begin{array}{c}\text { Viscosity } \\
\text { at } 135^{\circ} \mathrm{C}(\mathrm{mPa} \mathrm{s})\end{array}$ \\
\hline
\end{tabular}

\subsection{Polyethylene terephthalate}

In this research work waste PET have been used as additives, its main properties are shown in table 2. PET was collected from post-consumer, washed and dried. After that was melted and grinded by grinder machine, the granule PET particles were sieved. The sieve analyses indicated that $61 \%$ of PET passed through $0.300 \mathrm{~mm}$ sieve, $19 \%$ through $0.425 \mathrm{~mm}$ sieve and $19.6 \%$ through
$0.600 \mathrm{~mm}$ sieve (Figure 1). In this study three different percentage of granule PET were used, which was $(0.5 \%, 0.7 \%, 1.0 \%)$ by weight of asphalt binder.
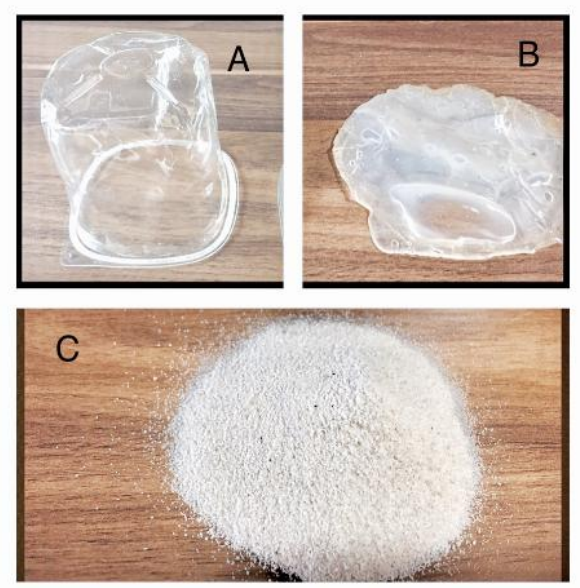

Figure 1. PETW sample: $(A)$ disposable cup, $(B)$ melt and $(C)$ granule of waste

Slika 1. PETW uzorak: (A) šolja za jednokratnu upotrebu, (B) taloženje $i$ (C) granule otpada

Tabela 2. Fizičke osobine PET otpada

Table 2. Physical properties of waste PET

\begin{tabular}{|c|c|c|}
\hline Melting point & Thermal conductivity & Density \\
\hline $255^{\circ} \mathrm{C}$ & 0.15 to $0.24 \mathrm{~W} \mathrm{~m}^{-1} \mathrm{~K}^{-1}$ & $1370 \mathrm{~kg} / \mathrm{m}^{3}$ \\
\hline
\end{tabular}

\subsection{Samples preparation}

Asphalt binder was heated to a temperature about $(160 \pm 10){ }^{\circ} \mathrm{C}$ to become more viscose [2], the ratios designed of PET granules added to the binder gradually to prevent the formation of conglomerates, by the method of wet process (( two different methods using to add polymers in asphalt mixture, wet and dry methods. In the wet method process, the additives are added to the asphalt cement before mixing with aggregate particles. In the dry method, the polymer mixed with the aggregate before adding asphalt)). The modifier asphalt was prepared by using high speed shear mixer (RH basic 2 type magnetic stirrer from IKA, Germany, speed $2000 \mathrm{rpm}$ ) at a temperature about $160^{\circ} \mathrm{C} \_170^{\circ} \mathrm{C}$ for 2 hours to uniformly disperse PET in binder and get homogenous blend [17].

\subsection{Characterization}

Samples were characterized by using of standard physical tests depend on the Asphalt Institute Manual (MS-17) to evaluate the influence of adding PET to asphalt on binder characteristics. The penetration of modified asphalt was measured according to ASTM D-5, "Standard Test Method for Penetration of Bituminous Materials" (temperature, 
load and time are $25^{\circ} \mathrm{C}, 100 \mathrm{~g}$ and $5 \mathrm{sec}$ respectively).

Softening point was measured by ASTM D-36, "Standard Test Method for Softening Point of Bitumen (Ring-and-Ball Apparatus)". The ductility at $25^{\circ} \mathrm{C}$ for asphalt cement was tested according to ASTM D-113, "Standard Test Method for Ductility of Bituminous Materials"(at $25^{\circ} \mathrm{C}$ and with speed of 5 $\mathrm{cm} / \mathrm{min}$ ).

Temperature susceptibility of asphalt cement conducted by determining the penetration softening point relationship using penetration index equation (PI) and stiffness of asphalt binder measured by using Van der Poel's nomograph.

The Fourier Transform Infrared (FT-IR) analysis were recorded from Shimadzu Corporation, Japan. Scans were taken in the range $3600-4000 \mathrm{~cm}^{-1}$. Measurements were made at University of Kufa, faculty of Pharmacy laboratory.

\section{RESULTS AND DISCUSSION}

\subsection{Physical properties}

The addition of PET to the asphalt binder was instigated the influences on physical properties as following:

\subsubsection{Penetration}

The penetration test of bitumen is the representation adhesion and measure the consistency of bitumen [17]. Figure 2. shows the relationship between the penetration values and waste PET content, and illustrated the decreasing of penetration value with increasing of PET percentage because of the molecular components in asphalt (aliphatic, cyclic, and aromatic.) will be reduce their influence by the effect of physical absorption when the polymer will be added and harder consistency of (PET-asphalt) binder [18].

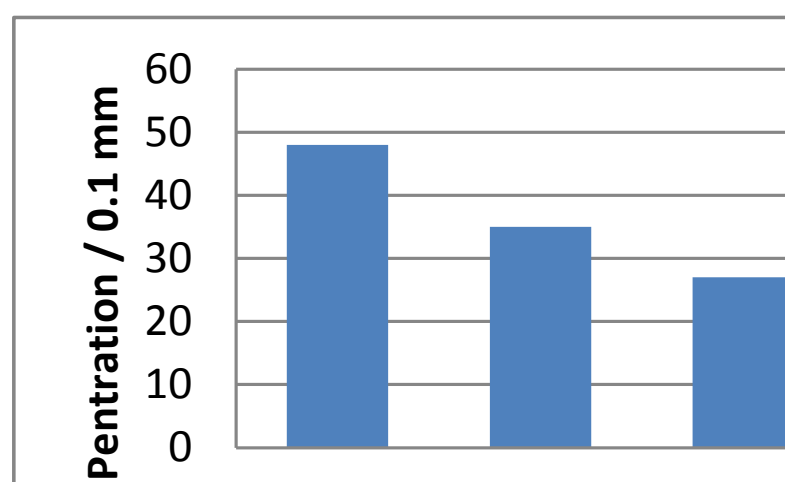

Figure 2. Penetrations of modified asphalt

Slika 2. Penetracije modifikovanog asfalta

\subsubsection{Softening point}

The softening point is the temperature which the bitumen changes from the solid state to the fluid state during an increase in temperature with the presence of designer external force. Figure 3 shows the relationship between softening point of modified binders and PET contents. The changes in softening point indicate that achieved improvement in temperature susceptibility of the modified bitumen due to adding polymer and it will be increase with the increasing of PET content. At the softening point, asphalt is likely to show bleeding on the hot road surface under heavy traffic. For hot climates, asphalt with higher softening point is preferred, thus, binder with high temperature stability to reduce its tendency to soften in hot weather [15].

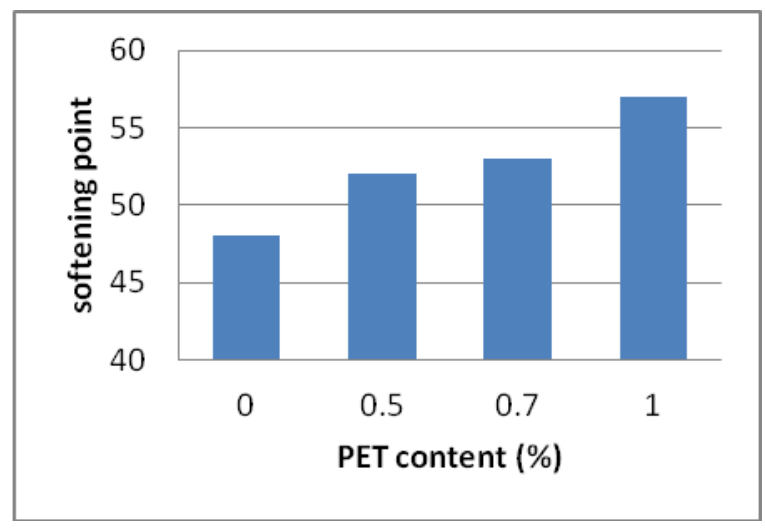

Figure 3. Softening point of modifier asphalt

\section{Slika 3. Tačka omekšavanja modifikatora asfalta}

\subsubsection{Ductility}

Ductility is usually used to measuring the distance to which it will elongate before breaking when tow ends of a briquette specimen of the material are pall apart at a specified speed and temperature, and use to evaluation of lowtemperature anti-cracking performance of asphalt binder. Figure 4 . shows the change in ductility value of binder and PET contents. The additive reduction in ductility at $25^{\circ} \mathrm{C}$ is due to stiffening of the asphalt binder by adding of PET [19].

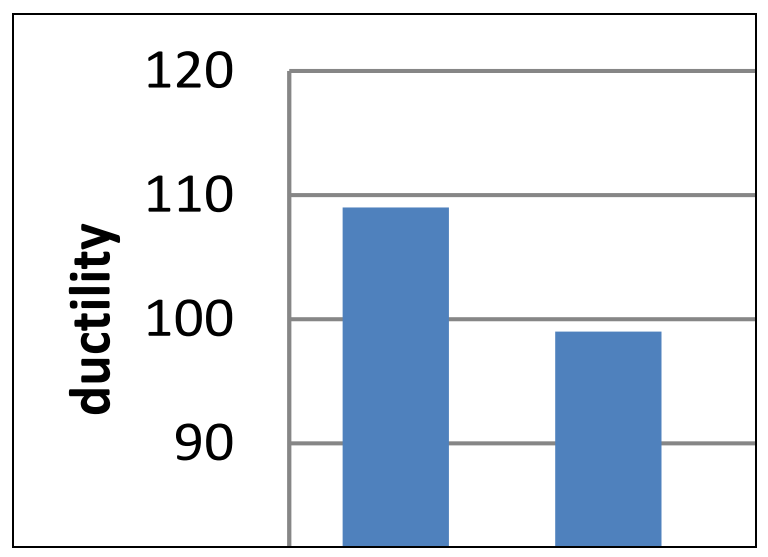

Figure 4. Ductility of modified asphalt

Slika 4. Duktilnost modifikovanog asfalta 


\subsection{Stiffness}

Binder stiffness has been determined from Van der Poel's nomograph [20] for a number of variables:

- One binder type (grade 40-50).

- Time of loading was $0.02 \mathrm{sec}$ which are approximately corresponded to traffic speed of $50 \mathrm{Km} / \mathrm{hr}$.

- Temperature range from $0^{\circ} \mathrm{C}$ to $60^{\circ} \mathrm{C}$.

- Three PET contents: 0.50, 0.75 and $1.00 \%$.

Temperature susceptibility was measured by using Penetration index $(\mathrm{PI})$ relationship which is an approach to characterize the effect of temperature on asphalt cement. This index is based on penetration plus softening point as follow:

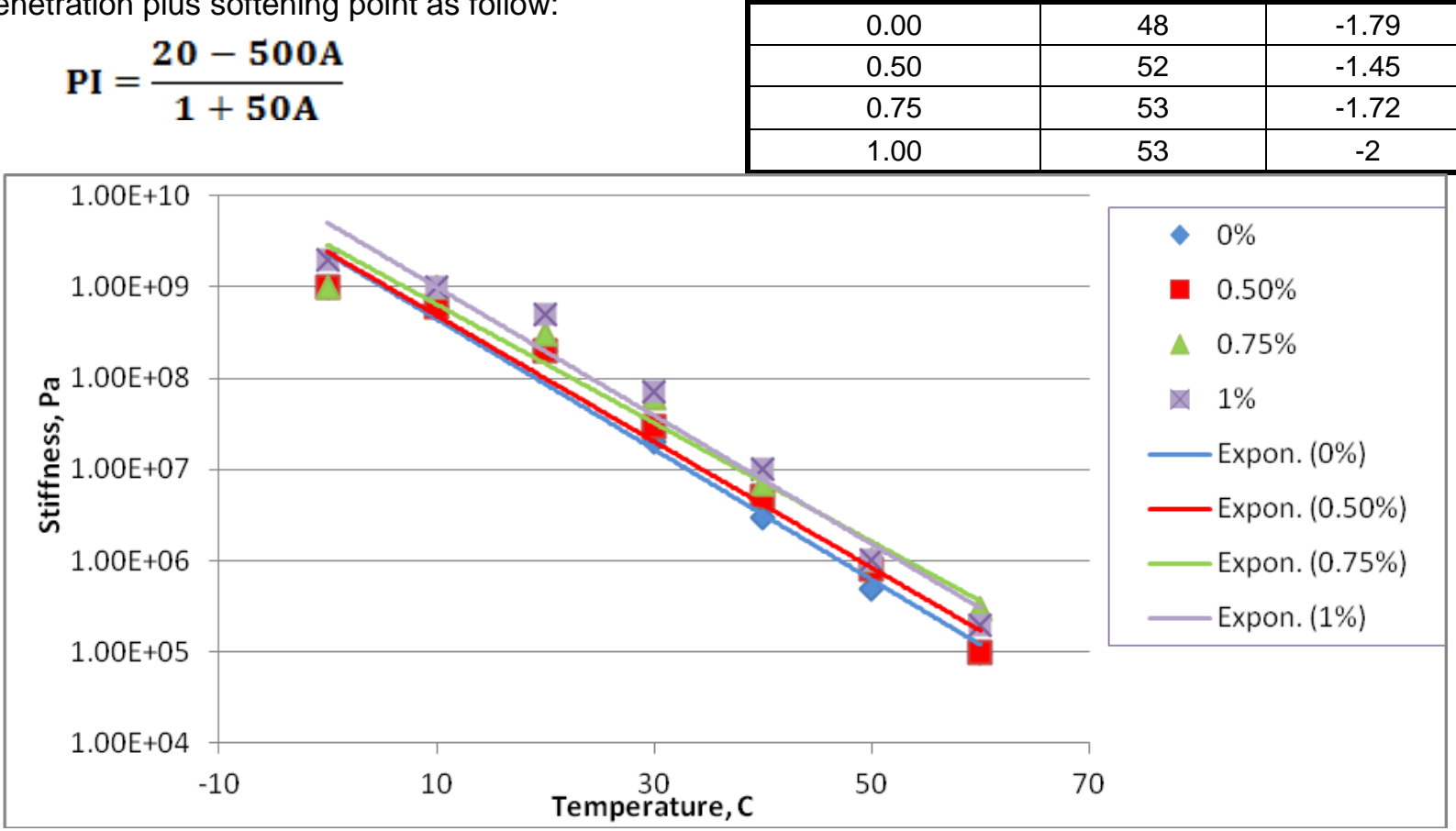

Figure 5. Stiffness modulus at different temperature

Slika 5. Modul čvrstoće na različitim temperaturama

Figure 5. illustrate the stiffness value for different waste PET content of asphalt binders at different temperature at the same loading time. From this figure it can be obtained that in hot climate, the adding of waste PET had resulted in mixtures with sufficient stiffness to avoid permanent deformation under traffic loading [20].

\subsection{FTIR spectroscopy}

The IR spectrum for both virgin and modified asphalt binder was measured. Figure 5 a (for raw asphalt binder) has peaks in the region 3437-2924 $\mathrm{cm}^{-1}, 2852 \mathrm{~cm}^{-1}, 1616 \mathrm{~cm}-1,1458 \mathrm{~cm}^{-1}, 1375 \mathrm{~cm}^{-1}$ and $1375 \mathrm{~cm}^{-1}$ which are represent to amine $\mathrm{N}-\mathrm{H}$, aliphatic and aromatic $\mathrm{C}-\mathrm{H}$ stretching vibration bands, amines $\mathrm{C}-\mathrm{N}$, and $\mathrm{C}-\mathrm{H}$ bending vibration

$$
A=\frac{\log 800-\log \mathbf{p}}{\mathbf{T} 2-\mathbf{T} \mathbf{1}}
$$

where: $\mathrm{P}$, penetration value; $\mathrm{T} 2$, Ring and Ball softening point; and $\mathrm{T} 1,25^{\circ} \mathrm{C}$

Higher value of P.I indicate lower temperature susceptibility [21]. Table 3 illustrates the P.I value for modified and unmodified asphalt cement samples.

Tabela 3. P.I. vrednost za modifikovani i nemodifikovani asfaltni cement

Table 3. P.I. value for modified and unmodified asphalt cement

\begin{tabular}{|c|c|c|}
\hline PET content $\%$ & $\mathrm{~T} \mathrm{r} \& \mathrm{~b},{ }^{\circ} \mathrm{C}$ & \\
\hline 0.00 & 48 & -1.79 \\
\hline 0.50 & 52 & -1.45 \\
\hline 0.75 & 53 & -1.72 \\
\hline 1.00 & 53 & -2 \\
\hline
\end{tabular}




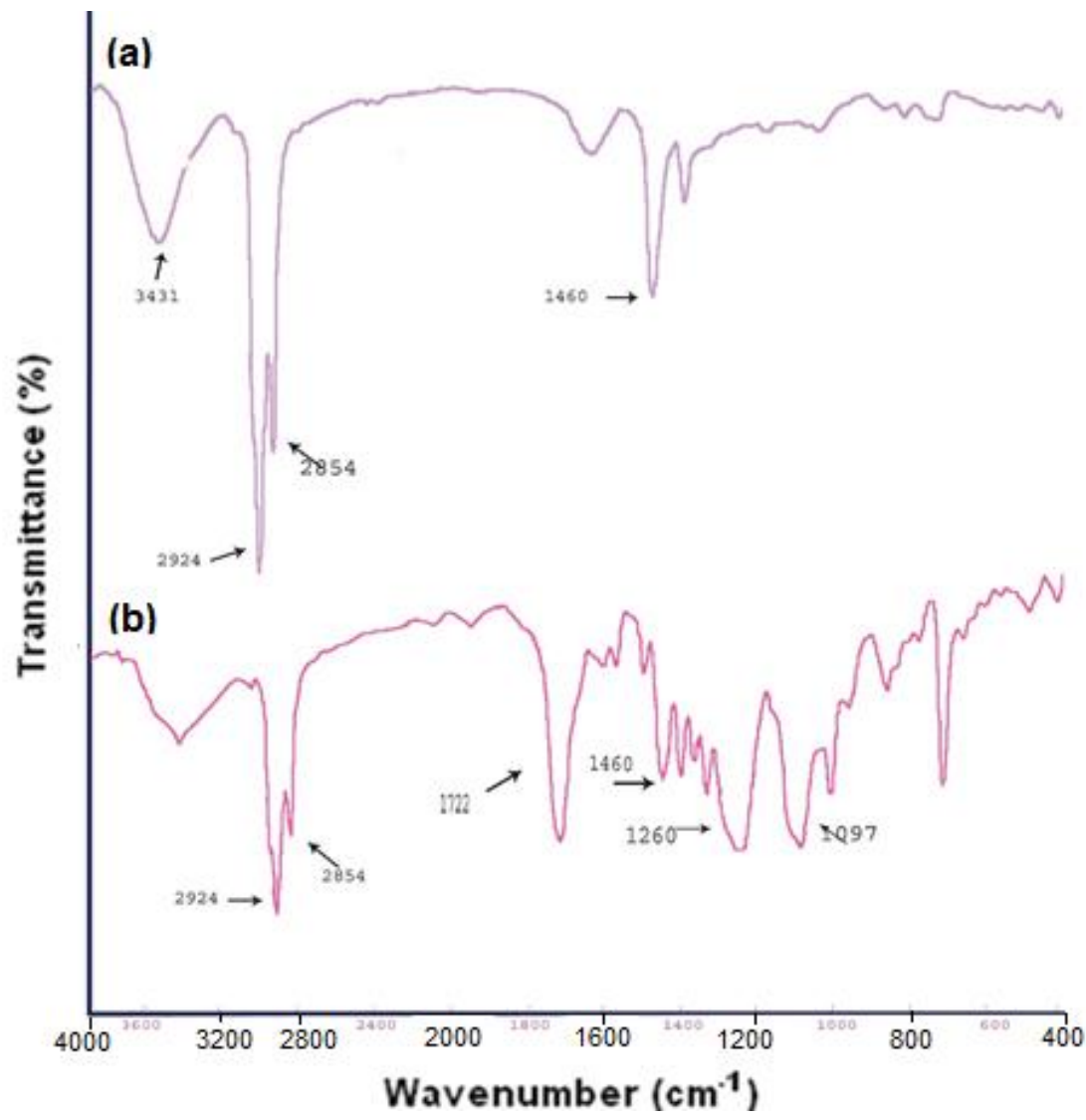

Figure 6. FTIR spectra of (a) virgin and (b) modified asphalt binder

Slika 6. FTIR spektri (a) čisto vezivo (b) modifikovano asfaltno vezivo

\section{CONCLUSIONS}

This study focused on a laboratory assessment of using waste PET as a binder modified and it was presented according to the conventional properties. Results show:

1. An obvious increase stiffness of the modified binder in high temperatures which means declined their temperature susceptibility. Characterization summaries that modification using additives able to improve the high temperature stability performance and not adversely affected in low temperature.

2. Penetration index values indicated that waste PET reduced the temperature susceptibility of asphalt and the optimum amount was $0.75 \%$ PET content which give higher P.I value.

3. Penetration at $25^{\circ} \mathrm{C}$ will decrease as PET content increases, which indicates improve in shear resistance in medium to high temperatures.

4. The addition of PET kept the ductility values close from the minimum range of ASTM specifications of $100 \mathrm{~cm}$.

5. Softening point for all modified sample was increased hence, resistance to deformation.

\section{REFERENCES}

[1] L.Sun, X.Xin, J.Ren (2017)Asphalt modification using nano-materials and polymers composite considering high and low temperature performance, Constr. Build. Mater., 133, 358-366.

[2] T.Baghaee Moghaddam, M.R.Karim, T.Syammaun (2012) Dynamic properties of stone mastic asphalt mixtures containing waste plastic bottles, Constr. Build. Mater., 34, 236-242.

[3] M.El-Shafie, I.M.Ibrahim, M.M.Abd El Rahman (2014) The addition effects of macro and nano clay on the performance of asphalt binder, Egypt. J. Pet., 21( 2), 149-154.

[4] T.Baghaee Moghaddam, M. Soltani, M. R. Karim (2014) Experimental characterization of rutting performance of Polyethylene Terephthalate modified asphalt mixtures under static and dynamic loads, Constr. Build. Mater., 65, 487-494.

[5] I.Journal, O.F.Applied (2015-16) Laboratory study on nano clay modified asphalt pavement Laboratory Study on Nano Clay Modified Asphalt Pavement.

[6] E.Ahmadinia, M.Zargar, M.R.Karim, M.Abdelaziz, E. Ahmadinia (2012) "Performance evaluation of utilization of waste Polyethylene Terephthalate (PET) in stone mastic asphalt, Constr. Build. Mater., 36, 984-989.

[7] S.Hellwig, A.Karri (2015) Comparing rubber modified asphalt to conventional asphalt Asses- 
sment of Trafikverket 's road survey tool, book, p.126.

[8] C.Te Chiu, L.C.Lu (2007) A laboratory study on stone matrix asphalt using ground tire rubber, Constr. Build. Mater., 21(5), 1027-1033.

[9] A.O.Sojobi, S.E.Nwobodo, O.J.Aladegboye, F.G. Pratico (2016) Recycling of polyethylene terephthalate (PET) plastic bottle wastes in bituminous asphaltic concrete, Cogent Eng., 3(1), 1133480.

[10] C.Fang, R.Yu, Y.Zhang, J.Hu, M.Zhang, X.Mi (2012) Combined modification of asphalt with polyethylene packaging waste and organophilic montmorillonite, Polym. Test., 31(2), 276-281.

[11] B.E.C.Engineer, W.Alexander (2013) A sustainable maintenance method for cracked pavements using polyester asphalt reinforcement. Increase pavement life, reduce maintenance and create sustainable pavements. Dipl.-Ing. Christoph Hessing, Area Manager.

[12] Z.Z.Ismail, E.A.AL-Hashmi (2008) Use of waste plastic in concrete mixture as aggregate replacement, Waste Manag., 28(11) 2041-2047.

[13] Y.Li, D.J.White, R.Lee Peyton (1998) "Composite material from fly ash and post-consumer PET, Resour. Conserv. Recycl., 24(2), 87-93.

[14] V.W.Y.Tam, C.M.Tam (2006) A review on the viable technology for construction waste recycling, Resour. Conserv. Recycl., 47(3), 209-221.

[15] A.Mahrez, M.R.Karim (2010) Rheological Evaluation of Bituminous Binder Modified With Waste Plastic Material, book.
[16] M.Soltani, T.B.Moghaddam, M.R.Karim, H.Baaj (2015) Analysis of fatigue properties of unmodified and polyethylene terephthalate modified asphalt mixtures using response surface methodology, Eng. Fail. Anal., 58, 238-248,

[17] I.M.Nassar, K.I.Kabel, I.M.Ibrahim (2012) Evaluation of the Effect of Waste Polystyrene on Performance of Asphalt Binder, ARPN J. Sci. Technol., 2(10), 927-935.

[18] M.A.H.Al-jumaili (2016) Modification of Asphalt Cement Properties and Chemical Properties by Polyprolene and Cellulose Additives, Cogent Eng., 2 (1), 33-39.

[19] B.Golestani, B.H.Nam, F.Moghadas Nejad, S. Fallah (2015) Nanoclay application to asphalt concrete: Characterization of polymer and linear nanocomposite-modified asphalt binder and mixture, Constr. Build. Mater., 91, 32-38.

[20] A.Gorden ( 1997 ) Rheological characteristics of polymer modified and aged bitumens, PhD thesis , University of Nottingham, Nottingham, G.B.

[21] A.I.Al-Hadidy, T.Yi-qiu (2009) Effect of polyethylene on life of flexible pavements, Constr. Build. Mater., 23(3), 1456-1464.

[22] Z.Chen (2012) The Crystallization of Poly (ethylene terephthalate) Studied by Thermal Analysis and FTIR Spectroscopy, book, p. 219.

[23] N.Seifollah Nasrazadani, D.Mielke (2010) Tyler Springfield and Ramasamy, "Practical Applications of FTIR to Characterize Paving Materials, book, p. $0-5$.

\section{IZVOD}

\section{PRIPREMA ODRŽIVIH ASFALTNIH KOLOVOZA KORISTEĆI OTPAD OD POLIETILEN-TEREFTALATA KAO MODIFIKATORA}

Industrijski razvoj i savremeni stil života doveli su do širenja velike količine ne-biorazgradivog plastičnog otpada. Ovaj rad ima za cilj proučavanje efekata recikliranja plastičnog otpada iz polietilen-tereftalata (PET), koji je tip ambalažnog plastičnog otpada, kao modifikatora asfalta, za stvaranje održivog asfaltnog kolovoza i poboljšanje reoloških osobina i podnošljivosti temperature. PET otpad se mešao sa asfaltnim cementom u tri procentna odnosa $(0,5 \%, 0,75 \%$ i $1,0 \%)$ mase asfaltnog cementa. Performanse modifikovanih uzoraka asfalta su proučavane $i$ upoređene sa naizmeničnim asfaltnim vezivom. Penetracija, tačka omekšavanja i duktilnost su ispitivani kako bi se utvrdio uticaj dodavanja otpadnog PET u asfalt na karakteristike veziva i čvrstoće veziva na različitim temperaturama. Takođe, Posmatranjem ovih parametara je utvrđeno da je sve značajno poboljšano. Rezultati pokazuju da dodatak PETW ima značajan uticaj na reološko ponašanje $i$ krutost veziva na visokim temperaturama. Ova studija ukazuje na to da otpadni PET ima poboljšane karakteristike asfalta kako bi se smanjili troškovi asfaltiranja i smanjio probleme životne sredine od čvrstog otpada.

Naučni rad

Rad primljen: 28. 06. 2017.

Rad prihvaćen: 30.07 .2017$.

Rad je dostupan na sajtu: www.idk.org.rs/casopis

(c) 2017 Authors. Published by Inženjersko društvo za koroziju. This article is an open access article distributed under the terms and conditions of the Creative Commons Attribution 4.0 International license (https://creativecommons.org/licenses/by/4.0/) 